\title{
Pengembangan Modul Sosiologi untuk Peserta Didik Kelas XI IPS SMA
}

\author{
Bunga Soraya ${ }^{1}$, Ike Sylvia ${ }^{2}$ \\ ${ }^{1,2}$ Universitas Negeri Padang \\ Email: bungasoraya25@gmail.com, ikesylvia@fis.unp.ac.id
}

\begin{abstract}
Abstrak
Tujuan penelitian ini untuk menghasilkan modul pada materi integrasi sosial yang sesuai untuk digunakan dalam pembelajaran sosiologi kelas XI IPS di SMA Adabiah Padang. Jenis penilitian ini adalah R\&D memakai model 4 D. Penelitian ini ada 4 tahap yaitu: (1) Define merupakan tahap untuk mendefinisikan kebutuhan serta ketentuan-ketentuan dalam pembelajaran, (2) Design adalah perancangan yang bertujuan untuk merancang modul yang dikembangkan, (3) Development merupakan tahap pengembangan, (4) Disseminate merupakan tahap penyebaran produk yang dikembangkan. Kelayakan modul dilihat dari skor kelayakan yang didapatkan yang diolah menggunakan Microsoft excel. Uji coba lapangan produk dilakukan pada kelas XI IPS 1 di SMA Adabiah Padang dengan jumlah 24 peserta didik. Hasil penelitian menunjukkan bahwa: (1) sumber belajar modul ini sangat memadai untuk pembelajaran sosiologi dalam materi integrasi sosial (2) peserta didik setelah mengikuti pembelajaran dengan mengggunakan modul ini mendapatkan peningkatan kemampuan penguasaan materi dapat dilihat pada nilai akhir posttest yaitu 86,46 .
\end{abstract}

Kata kunci: Model 4D, Modul, Pembelajaran Sosiologi

\section{Abstract}

The purpose of this study is to produce a module on social integration material that is suitable for use in social studies class XI sociology learning at SMA Adabiah Padang. This type of research is $R \& D$ using $4 D$ models. This research has 4 stages, namely: (1) Define is the stage to define the needs and provisions in learning, (2) Design is a design that aims to design the developed module, (3) Development is the development stage, (4) Disseminate is a the stage of distribution of the product being developed. The feasibility of the module is seen from the feasibility score obtained which is processed using Microsoft excel. The product field trial was carried out in class XI Social Studies 1 at SMA Adabiah Padang with a total of 24 students. The results of the study show that: (1) the learning resources of this module are very adequate for learning sociology in social integration material (2) students after participating in learning using this module get an increase in their mastery of the material, which can be seen in the final posttest score of 86.46 .

Keywords: 4D Model, Module, Sociology Learning

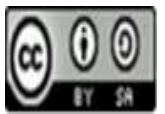

Received: August 4, $2021 \quad$ Revised: December 26, 2021

Accepted: December 27, 2021

\section{Pendahuluan}

Pendidikan adalah suatu metode memberikan pengalaman kepada peserta didik agar bisa menyesuaikan diri dengan lingkungan mereka saat ini. Melalui pendidikan terjadi proses pembelajaran yang akan menimbulkan perubahan diri pada individu yang akan bermanfaat dalam kehidupan masyarakat. Pendidikan bisa diperoleh dari insttutusi pendidikan formal dan non formal yang bertujuan mampu menambah pengetahuan, membentuk karakter diri dan mengarahkan peserta didik untuk menjadi orang yang lebih baik. Pendidikan adalah bagian penting dari kehidupan yang secara bersamaan mengenali perbedaan antara manusia dengan makhluk hidup lainnya. Upaya untuk memperluas kemajuan suatu bangsa, dapat dilaksanakan dengan memperluas mutu pendidikan yang dimulai dari tujuan pendidikan. Dalam pendidikan, terdapat proses transfer ilmu antara pendidikan dan peserta didik atau disebut dengan 
pembelajaran. Sekolah yang berkualitas diharapkan dapat menumbuhkan potensi diri, kepribadian yang baik dan kecerdasan intelektual.

Pembelajaran adalah perubahan tingkah laku secara terus menerus pada peserta didik yang disebabkan oleh pengalaman. Pengalaman menghasilkan perilaku dan pengetahuan sebagai upaya yang signifikan dalam mempersiapkan peserta didik untuk menjadi anggota masyarakat yang produktif. Dalam proses pembelajaran di sekolah, guru berperan sebagai pihak pertama dalam penyampaian pengetahuan, berupaya membentuk sikap dan keterampilan peserta didik dalam proses pembelajarannya. Oleh karena itu, guru dituntut inovatif dan kreatif dalam proses pembelajaran yang ada di kelas dengan cara menggunakan modul dan model pembelajaran yang bervariasi supaya peserta didik mampu menerima dan menangkap dengan baik.

Modul dapat diartikan sebagai sumber belajar yang dapat dipelajari secara mandiri oleh peserta didik untuk mencapai tujuan pembelajaran dengan bimbingan dari guru. (Santika \& Sylvia, 2021). Menurut Sudjana modul adalah program pengajaran yang disusun sebagai alat ukur yang lengkap dan individual untuk kebutuhan belajar mengajar. Modul adalah semacam unit program yang disusun dan dirancang untuk kebutuhan peserta didik dalam belajar secara mandiri. (Sudjana \& Rivai, 2007). Modul merupakan sebuah buku yang ditulis dengan tujuan supaya peserta didik bisa belajar secara individual. Modul yaitu sumber belajar yang praktis karena dapat digunakan untuk belajar kapanpun dan dimana saja. (Suntari, B., \& Widyarso, 2015). Menurut Mulyasa (Mulyasa, 2010) tujuan mendasar modul adalah untuk meningkatkan efisien dan efektivitas pembelajaran, baik waktu, dana fasilitas, dan tenaga guna mencapai tujuan secara ideal. Demikian modul juga dibuat dengan tujuan agar peserta didik dapat belajar mandiri sebagaimana dikatakan oleh Suparman, kemandirian belajar merupakan perilaku dan kemampuan peserta didik untuk melakukan kegiatan belajar secara individu maupun dengan bantuan orang lain berdasarkan motivasinya sendiri untuk menguasai suatu kompetensi tertentu sehingga dapat dimanfaatkannya untuk mengatasi masalah yang dihadapi. (Suparman, 2014).

Modul memiliki 5 karakteristik yaitu sebagai dapat sebagai self instruction, self contained, stand alone, adaptif, dan user friendly: (1) Self Instruction, peserta didik diharapkan belajar secara mandiri dan tidak bergantung dengan pihak lain. Self instruction bisa terpenuhi jika modul tersebut: berisi tujuan belajar yang jelas, materi pembelajaran dikemas dengan unit kegiatan yang menarik dan unik, adanya contoh dan gambar yang mendukung materi pembelajaran, kontekstual, memiliki bahasa yang sederhana, adanya ringkasan materi pembelajaran, dan adanya referensi. (2) Self Contained, semua materi pembelajaran yang diperlukan sudah ada di dalam modul. Karakteristik ini memberikan kesempatan kepada peserta didik untuk dipelajari materi dengan tuntas. (3) Stand Alone (berdiri sendiri), modul yang dikembangkan tidak terpaut dengan modul lain. (4) Adaptif (penyesuasain), modul mampu menyesuaikan perkembangan ilmu pengetahuan dan teknologi, fleksibel/luwes digunakan diberbagai perangkat keras (hardware). Modul yang adaptif merupakan jika modul tersebut dapat digunakan sampai kurun waktu tertentu. (5) User Friendly (bersahabat/akrab), modul mempunyai instruksi dan paparan informasi bersifat sederhana, mudah dipahami, juga menggunakan istilah yang umum digunakan. Penggunaan bahasa sederhana dan penggunaaan istilah yang umum digunakan adalah salah satu bentuk user friendly. (Direktorat Tenaga Kependidikan, 2008)

Menurut pendapat Piaget setiap individu dapat membangun wawasan mereka sendiri dengan berkomunikasi secara terus-menerus dengan keadaan mereka saat ini. (Gintings, 2008). Pandangan ini menjunjung tinggi perlu diadakannya modul yang secara tepat dapat diidentikkan dengan realitas dan memberikan kebebasan kepada peserta didik untuk terhubung secara efektif dengan keadaan mereka saat ini. Hal ini sesuai dengan kapasitas modul yang dapat dimanfaatkan oleh setiap orang dalam menilai pemahaman materi yang didapat.

Berdasarkan hasil observasi pembelajaran sosiologi di kelas XI IPS 1 SMA Adabiah Padang pada tahun pelajaran 2020/2021, ditemukan: (1) Peserta didik kurang berpartisipasi dalam belajar, karena peserta didik kurang terlibat dalam berpartisipasi aktif; (2) Sumber belajar yang disediakan pihak sekolah hanya buku paket; (3) Hasil belajar peserta didik rendah. Oleh karena itu, diperlukan

Jurnal Sikola: Jurnal Kajian Pendidikan dan Pembelajaran Vol. 3, No. 2, Th. 2021 
suatu upaya yang dapat membuat hasil belajar peserta didik meningkat, upaya yang dapat dilakukan yaitu penggunaan sumber belajar yang tepat dalam pembelajaran, salah satunya adalah modul.

Arif S Sadiman dalam Ahmad Rohani \& Abu Ahmadi mengatakan sumber belajar adalah berbagai sumber yang ada di luar yang memungkinkan terjadinya proses pembelajaran. (Ahmad, 1995). Peranan sumber belajar seperti: dosen, guru, buku, majalah, laboratorium, film, peristiwa, dan lain-lain. Memungkinkan individu berubah dari tidak tahu menjadi tahu, dari tidak paham menjadi paham, dari tidak kompeten menjadi berbakat, dan membuat orang siap untuk mengenali mana yang baik dan mana yang tidak baik. Sehingga semua yang dapat membawa manfaat atau mendukung banyak orang untuk berubah ke arah yang lebih baik, dinamis, atau menuju perkembangan bisa disebut sumber belajar.

Sumber belajar adalah segala yang dapat memberikan informasi dalam pembelajaran. Abdul Majid (Majid, 2008) mengatakan bahwa sumber belajar ditetapkan sebagai informasi yang disajikan dan disimpan dalam berbagai jenis media, yang dapat membantu peserta didik dalam belajar, sebagai perwujudan dari pendidikan. Bentuknya tidak dibatasi baik sebagai cetakan, video, perangkat lunak, atau kombinasi dari beberapa bentuk tersebut yang dapat digunakan peserta didik dan guru. Sumber belajar juga dapat diartikan sebagai semua tempat atau kondisi, individu, dan benda yang mengandung informasi yang menjadi wahana bagi peserta didik untuk menyelesaikan proses perubahan tingkah laku.

Berdasarkan uraian tersebut, maka diperlukan pengembangan modul sebagai sumber belajar yang dapat digunakan untuk memberikan manfaat dan memudahkan pelaksanaan proses pembelajaran sosiologi sehingga dapat meningkatkan kompetensi peserta didik. Oleh sebab itu, maka peneliti memandang perlu untuk mengembangan modul sosiologi pada materi integrasi sosial untuk kelas XI IPS SMA.

\section{Metode Penelitian}

Pada penelitian ini menggunakan jenis penelitian Research and Development (R\&D). Produk yang dikembangkan adalah modul materi integrasi sosial peserta didik pada pembelajaran sosiologi. Menurut Sugiyono, penelitian Research and Development (R \& D) yaitu strategi penelitian yang digunakan untuk menciptakan produk tertentu, dan menguji keefektifan dari produk yang dikembangkan. Pengembangan merupakan dalam proses untuk mengembangkan produk atau menyempurnakan produk yang sudah ada dan bisa dipertanggungjawabkan (Sugiyono, 2017).

\section{Model Pengembangan}

Model pengembangan yang digunakan dalam penelitian ini adalah model pengembangan yang dikemukakan oleh Thiagarajan yaitu $4 \mathrm{D}$, yang terdiri atas empat tahap yaitu define atau pendefinisian, design atau perancangan, develop atau pengembangan, dan disseminate atau penyebarluasan. (Thiagarajan, 1974).

Tahap pendefinisian (define) dilakukan untuk mendefenisikan kebutuhan dalam pengembangan pembelajaran sosiologi. Ada 5 langkah tahap pendefinisian yang dilakukan yaitu: (1) Analisis awal, pada tahap ini proses ditemukannya masalah penting dalam pembelajaran sosiologi antara lain; peserta didik kurang berpartisipasi dalam pembelajaran, karena peserta didik kurang dilibatkan untuk berpartisipasi aktif, sumber belajar yang disediakan pihak sekolah hanya buku paket, dan hasil belajar peserta didik rendah, sehingga diperlukan solusi alternatif berupa pengembangan modul yang menunjang proses pembelajaran sosiologi untuk mengatasi masalah yang dihadapi peserta didik; (2) Analisis karakteristik, pada tahap ini ditemukan karakteristik peserta didik, berdasarkan kemampuan belajar, psikologis, dan akademik (pengetahuan) peserta didik kelas XI IPS 1 di SMA Adabiah Padang yang berjumlah 24 peserta didik; (3) Analisis tugas bertujuan untuk mengidentifikasi Indikator, Kompetensi Inti, dan Kompetensi Dasar yang sesuai dengan program pendidikan 2013 yang dibutuhkan dalam pengembangan produk modul

Jurnal Sikola: Jurnal Kajian Pendidikan dan Pembelajaran Vol. 3, No. 2, Th. 2021 
sosiologi; (4) Analisis ide dilaksanakan dengan membedakan ide-ide pokok pada materi integrasi sosial, menggambarkan realitas dan menentukan secara sengaja menyusun ide-ide yang diidentifikasi dengan ide-ide yang dikaitkan dengan konsep integrasi sosial. (5) Pada tahap penentuan, tujuan pembelajaran dibedakan dan disusun berdasarkan rumusan Tujuan Pembelajaran, Kompetensi Inti (KI), dan Kompetensi Dasar (KD) yang tercatat di dalam rencana pendidikan.

Pada tahap ke-2 yaitu perancangan (design) dilakukan perancangan produk modul sosiologi yang akan dikembangkan. Ada beberapa tahap di lakukan dalam tahap ini antara lain: (1) Tahap perancangan modul, dalam tahap ini peneliti membuat sumber belajar yang akan dimanfaatkan untuk proses pembelajaran sosiologi yang disesuaikan dengan tahap define, dengan dilakukan perancangan pada format isi dalam penelitian ini berupa modul sosiologi; (2) Tahap pemilihan sumber belajar tujuannya untuk menentukan sumber belajar yang tepat dimanfaatkan dalam pembelajaran, supaya tujuan belajar dapat tercapai dan proses pembelajaran bisa berjalan secara efektif. Sumber belajar yang dipilih untuk penelitian ini berupa modul sosiologi pada materi integrasi sosial; (3) Tahap pemilihan format, berkaitan dengan pemilihan sumber belajar. Pemilihan format dipilih sesuai dengan program pendidikan 2013. Dalam tahap ini juga dilakukan pemilihan isi pembelajaran dan sumber belajar.

Pada tahap ke-3 yaitu pengembangan (develop) adalah tahap yang menghasilkan produk modul. Pada tahap pengembangan ada dua bagian yang dilakukan yaitu: (1) Tahap uji kelayakan produk, dalam tahap ini dimaksudkan untuk mengembangkan modul sebagai sumber belajar. Tahap ini untuk mendapatkan evaluasi, dan masukan atau komentar dalam pengembangan modul supaya lebih layak dan sesuai dengan tujuan belajar; 2) Uji coba produk dilaksanakan untuk memperoleh gagasan sebagai tanggapan atau komentar dari dosen validator sebagai sasaran pengguna produk dan para pengamat terhadap produk yang telah dirancang. Dalam tahap ini dilaksanakan uji coba produk kepada subjek yang akan di ujicobakan dengan peserta didik kelas XI IPS 1 di SMA Adabiah Padang pada pembelajaran sosiologi materi integrasi sosial.

Selanjutnya pada tahap ke-4 yaitu penyebarluasan (disseminate) yaitu penggunaan produk modul yang sudah dikembangkan untuk materi integrasi sosial, kemudian disebarluaskan melalui uji coba pada peserta didik kelas XI IPS 1 di SMA Adabiah Padang. Hal ini dimaksudkan untuk memperoleh respon terhadap modul yang telah dikembangkan. Produk akhir yang didapatkan pada tahap ini adalah hasil pengukuran efektifitas dari modul yang telah diujicobakan penggunaannya dalam pembelajaran materi integrasi sosial.

\section{Teknik Pengumpulan Data}

Dalam proses pengembangan modul sosiologi dengan materi integrasi sosial, teknik pengumpulan data yang digunakan antara lain melalui: (1) Observasi yaitu suatu cara pengamatan langsung dan secara sistematis terhadap objek yang diteliti. Teknik observasi ini bertujuan untuk mengetahui analisis awal, analisis karakteristik, analisis tujuan, analisis tugas, analisis ide, dan penentuan tujuan, materi, dan sumber belajar yang digunakan; (2) Wawancara, teknik wawancara bertujuan untuk digunakan sebagai teknik pengumpulan data untuk menemukan masalah dalam proses pembelajaran sosiologi di kelas XI IPS 1 SMA Adabiah Padang; (3) Dokumen, digunakan untuk mengetahui dokumentasi proses dan hasil belajar peserta didik; (4) Angket, menurut Sugiyono angket adalah teknik pengumpulan data yang dilakukan dengan cara memberi pernyataan tertulis kepada responden (Sugiyono, 2017). Pada penelitian ini angket dikembangkan sebagai instrumen penelitian untuk mengukur validitas modul yang diberikan kepada ahli untuk mengukur tingkat keterpercayaan modul yang dikembangkan sebagai sumber belajar yang diharapkan mampu meningkatkan kompetensi peserta didik; (4) Tes, teknik tes bertujuan untuk mengukur efektifitas modul yang telah diujicobakan, dengan memberikan soal pada pretest dan posttest sebagai teknik untuk mengetahui kemampuan kognitif peserta didik. Sebelum modul diberikan terlebih dahulu dilakukan pretest untuk mengetahui kemampuan awal peserta didik, dan

Jurnal Sikola: Jurnal Kajian Pendidikan dan Pembelajaran Vol. 3, No. 2, Th. 2021 
akhir pembelajaran dilakukan posttest untuk mengetahui kemampuan akhir peserta didik setelah mengikuti pembelajaran menggunakan modul sosiologi pada materi integrasi sosial.

\section{Teknik Analisis Data}

Teknik analisis data kualitatif digunakan untuk mendapatkan data pada tahap define dari hasil observasi, wawancara dan dokumen, peneliti melakukan triangulasi data untuk memperoleh keputusan terbaik sebelum melakukan perancangan modul sosiologi materi integrasi sosial yang sesuai dengan permasalahan dan tujuan pembelajaran. Setelah itu data kuantitatif berupa hasil pengukuran kelayakan modul yang telah dilakukan berdasarkan penilaian dari validator, kemudian dianalisis menggunakan rumus Aikens'V. Kemudian data yang diperoleh dari hasil uji efektifitas modul (hasil pretest dan posttest) selanjutnya dianalisis dengan uji t-test. Hasil kelayakan modul diinterpretasikan dengan kategori sebagai berikut:

\section{Tabel 1. Interpretasi Koefisien Korelasi}

\begin{tabular}{lll}
\hline No. & Interval Koefisien & Interpretasi \\
\hline 1. & $0,00-0,199$ & Sangat Rendah \\
\hline 2. & $0,20-0,399$ & Rendah \\
\hline 3. & $0,40-0,599$ & Sedang \\
\hline 4. & $0,60-0,799$ & Kuat \\
\hline 5. & $0,80-1$ & Sangat Kuat \\
\hline
\end{tabular}

Sumber: Sugiyono (Sugiyono, 2017)

\section{Hasil dan Pembahasan}

\section{Hasil}

Ada 4 (empat) tahap yang dilakukan peneliti dalam menghasilkan produk modul sosiologi yang layak yaitu define, design, develop, dan disseminate. Penelitian ini bertujuan untuk mengembangkan modul sosiologi sebagai sumber belajar pada materi integrasi sosial untuk meningkatkan kemampuan penguasaan konsep peserta didik dan mengatasi masalah yang dihadapi peserta didik. Berikut ini 4 tahap yang dijabarkan

\section{Tahap Define (Pendefinisian)}

Tahap define atau tahap definisi adalah tahap pertama dalam proses pengembangan modul sosiologi. Dalam tahap ini dilakukan analisis awal, analisis peserta didik, analisis tugas, dan analisis materi.

Tahap analisis awal adalah tahap utama yang dilakukan untuk memperoleh data tentang masalah yang terjadi sebagai persyaratan untuk pengembangan modul. Dari hasil pengamatan dan wawancara, ditemukan permasalahan yang terjadi yaitu peserta didik kurang aktif dalam pembelajaran, sumber belajar hanya menggunakan buku paket, dan hasil belajar peserta didik rendah. Tahap analisis peserta didik dilakukan untuk mengetahui karakteristik peserta didik yang akan menjadi subjek penelitian. Analisis peserta didik dimaksudkan untuk menganalisis karakter peserta didik seperti kemampuan akademik dan kemampuan penguasaan materi belajar peserta didik. Pada penelitian ini peserta didik yang akan menjadi subjek penelitian yaitu peserta didik kelas XI IPS 1 SMA Adabiah Padang yang berjumlah 24 orang peserta didik. Hasil analisis karakteristik peserta didik yang diamati pada kelas XI IPS 1 di SMA Adabiah. Hasil dari analisis ini yaitu kemampuan penguasaan materi peserta didik (kognitif) masih rendah, dan rasa percaya diri peserta didik juga masih rendah. Setelah dilakukan analisis peserta didik, pada analisis berikutnya adalah analisis tugas yang bertujuan untuk memutuskan materi yang akan dimuat untuk modul pembelajaran. Analisis tugas meliputi analisis kompetensi inti (KI), kompetensi dasar (KD), dan menggambarkan petunjuk-petunjuk pembelajaran yang sesuai dengan program pendidikan 2013. 
Analisis materi dimaksudkan untuk menyusun materi secara mendalam dan sistematis materi, isi, pengelompokkan materi dalam modul pembelajaran. Analisis materi dilakukan untuk mengetahui ide materi yang akan dikembangkan dalam sumber belajar yang disesuaikan dengan pembelajaran sosiologi. Materi dikembangkan menjadi modul yaitu integrasi sosial.

\section{Tahap Design (Perancangan)}

Tahap kedua dari model pengembangan $4 \mathrm{D}$ yaitu tahap rencana yang merupakan tahap yang berfokus pada rencana yang mendasari produk modul. Konsekuensi dari rencana dasar ini adalah sebagai rencana garis besar modul yang dikembangkan pada materi integrasi sosial. Pada tahap design ini terdiri dari beberapa bagian yang meliputi tahap rancangan modul, pemilihan format, dan penyusunan instrumen.

Rancangan produk dalam penelitian ini adalah modul sosiologi pada materi integrasi sosial. Penyusunan materi untuk modul ini mengambil referensi dari buku dan internet yang sudah disesuaikan dengan kemampuan peserta didik dalam pembelajaran sosiologi.

Tabel 2. Bagian-bagian Modul

\begin{tabular}{lll}
\hline No. & \multicolumn{1}{c}{ Bagian modul } & \multicolumn{1}{c}{ Keterangan } \\
\hline 1. & Cover/ Sampul & $\begin{array}{l}\text { Berisi judul materi modul, identitas yang membuat modul, sasaran } \\
\text { pengguna yaitu peserta didik kelas XI IPS 1. }\end{array}$ \\
\hline 2. & Menu utama & Peta konsep \\
\hline 3. & Menu petunjuk & Berisi petunjuk penggunaan modul \\
\hline 4. & Menu KI \& KD & $\begin{array}{l}\text { Berisi Kompetensi Inti (KI), Kompetensi Dasar (KD), Indikator } \\
\text { Pencapaian Kompetensi (IPK), dan Tujuan Pembelajaran. }\end{array}$ \\
\hline 5. & Menu materi & Berisi penjelasan materi Integrasi Sosial \\
\hline 6. & Rangkuman & Berisikan rangkuman materi dari awal sampai akhir pada modul. \\
\hline 7. & Menu sumber & $\begin{array}{l}\text { Berisi kumpulan sumber atau informasi referensi yang digunakan } \\
\text { untuk acuan penyusunan materi. }\end{array}$ \\
\hline & & Sumber: Hasil Penelitian (2021).
\end{tabular}

Pemilihan format yang digunakan dalam pengembangan rancangan modul sosiologi dalam bentuk cetak pada materi integrasi sosial. Berikut format modul yang dikembangkan meliputi:

1. Judul modul yaitu "Integrasi Sosial".

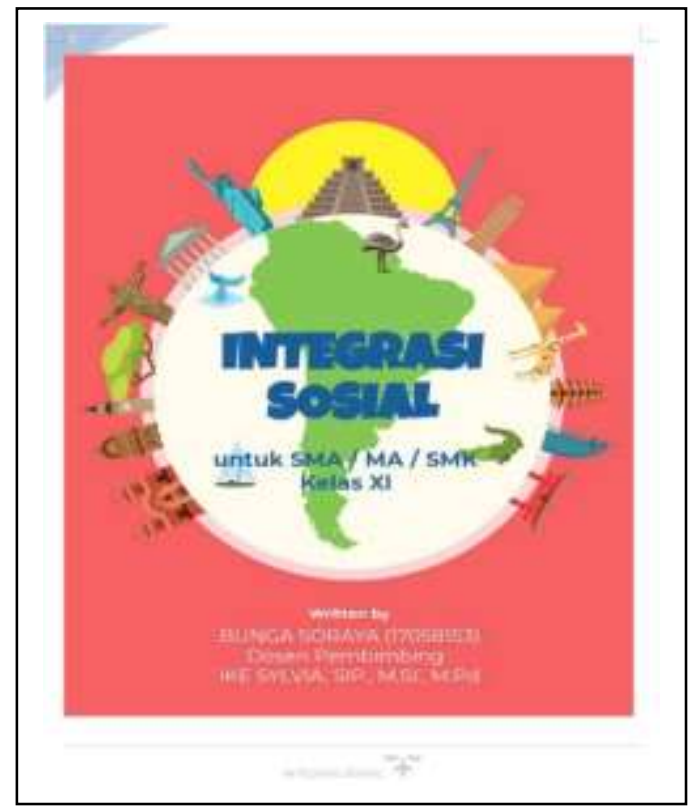

Gambar 1. Cover Modul

Jurnal Sikola: Jurnal Kajian Pendidikan dan Pembelajaran Vol. 3, No. 2, Th. 2021 
2. Pada halaman 2 dan 3 terdapat daftar isi, $\mathrm{KI}, \mathrm{KD}$, dan petunjuk penggunaan modul yang dikembangkan.

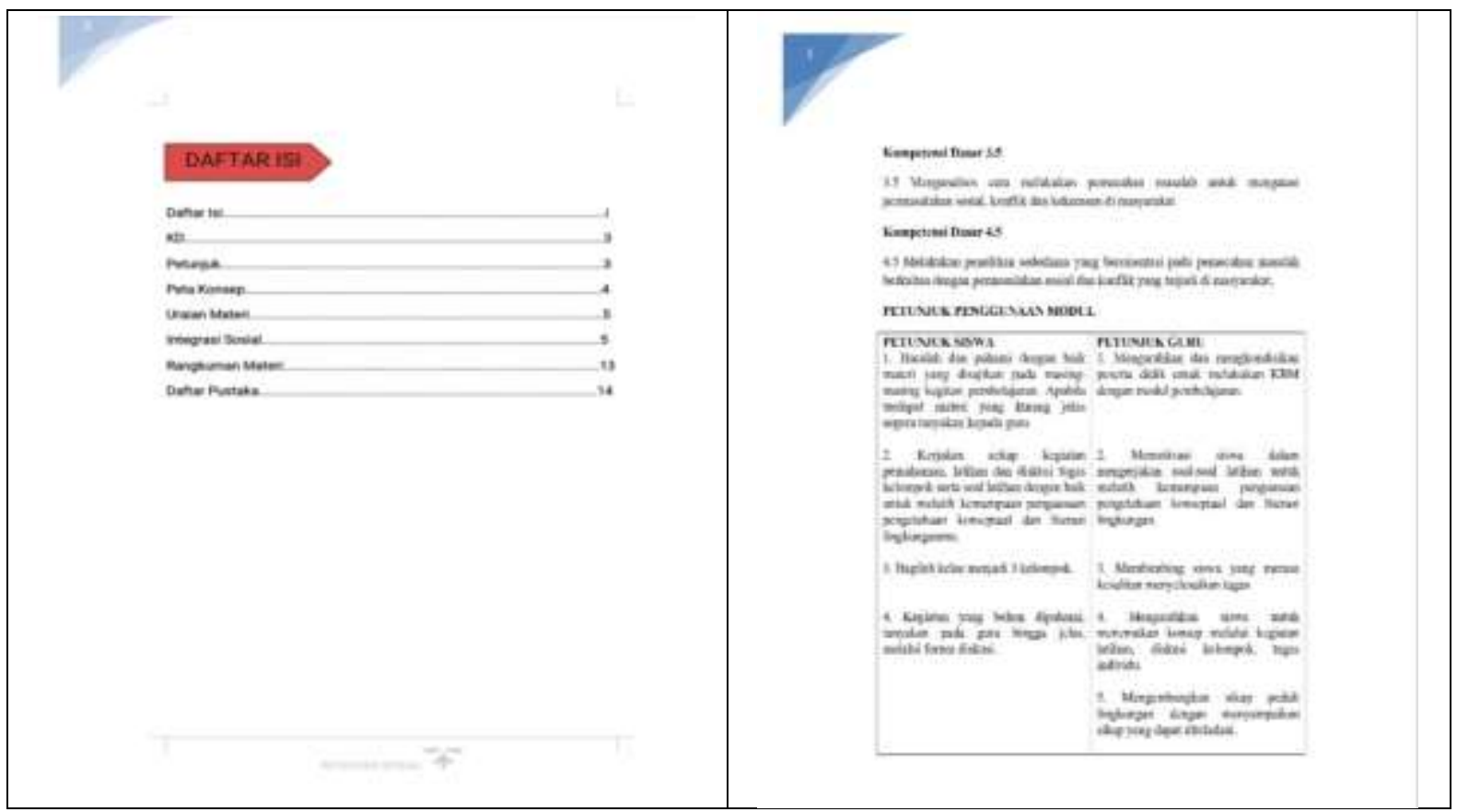

Gambar 2. Daftar Isi dan KI, KD, dan Petunjuk Penggunaan

3. Halaman 4 berisikan peta konsep materi integrasi sosial. Peta konsep ini menggambarkan halhal yang penting yang sesuai dengan materi.

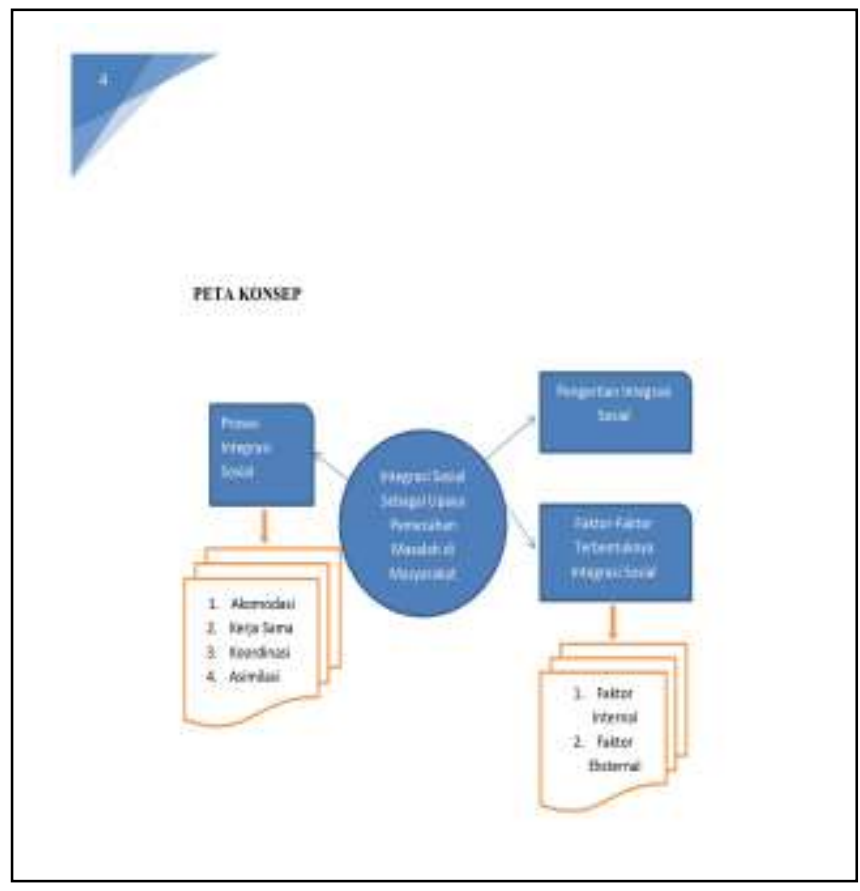

Gambar 3. Peta Konsep

Jurnal Sikola: Jurnal Kajian Pendidikan dan Pembelajaran Vol. 3, No. 2, Th. 2021 
4. Isi materi dalam modul dirancang secara urut dan sistematis.

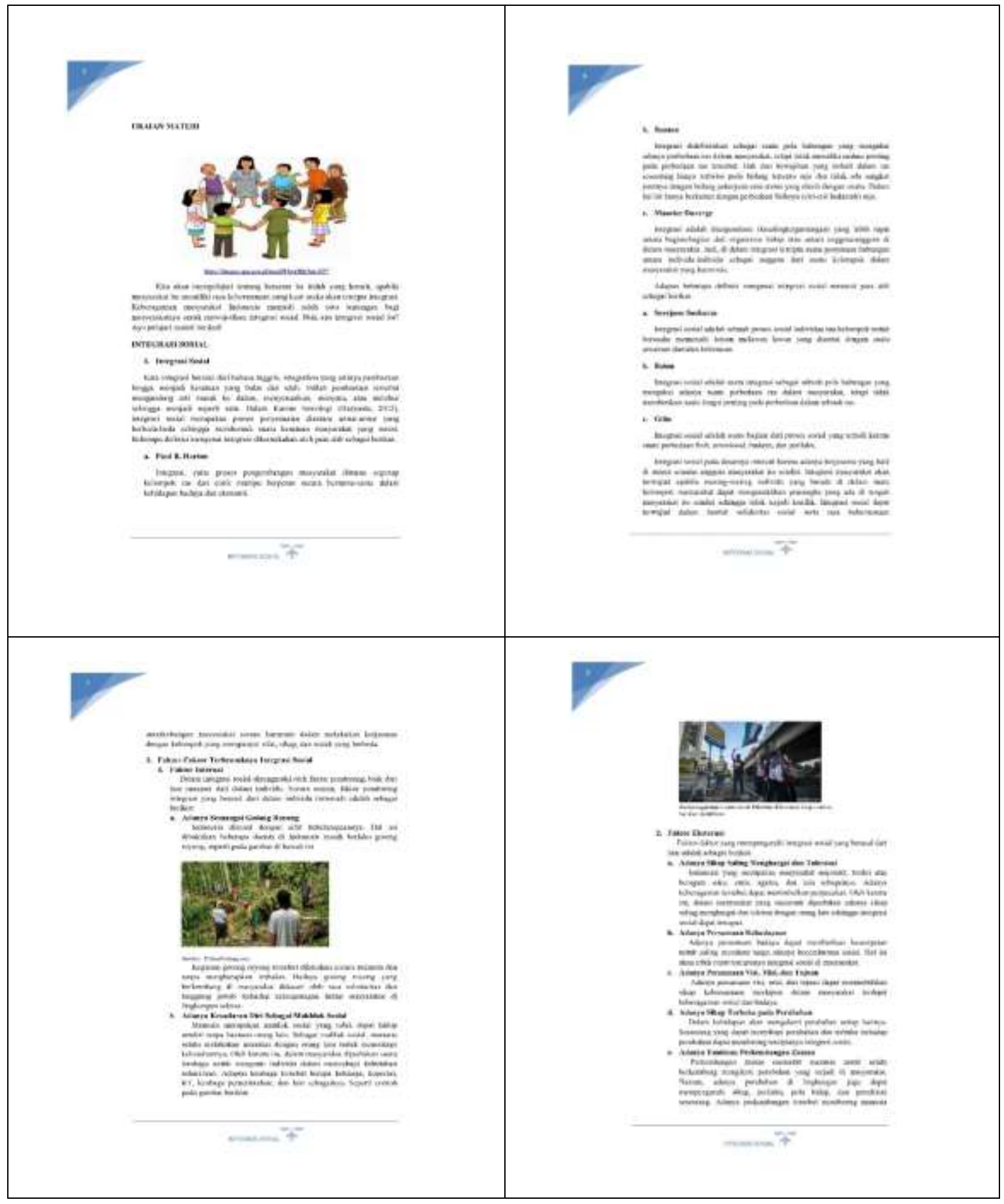




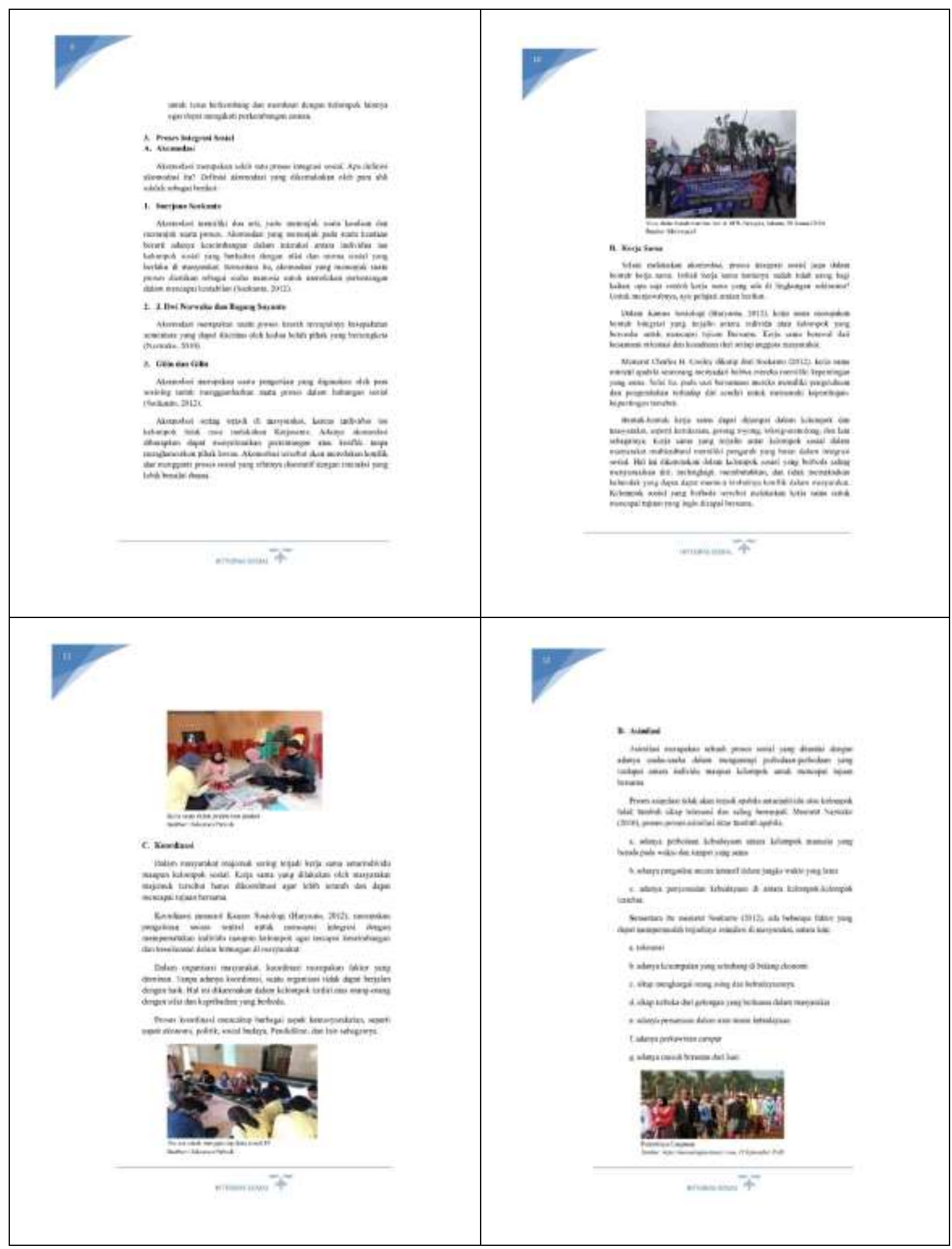

Gambar 4. Isi Materi 
5. Pada akhir materi terdapat rangkuman materi yang ada pada modul.

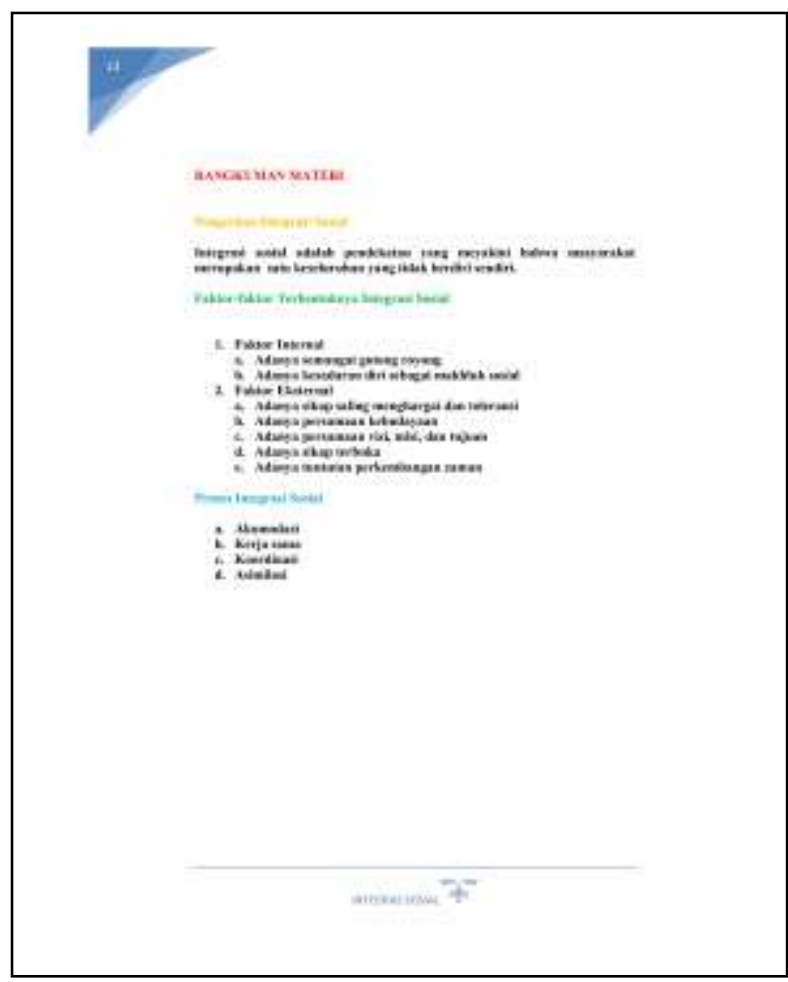

Gambar 5. Rangkuman Materi

Sesudah menentukan rancangan produk modul sosiologi materi inteegrasi sosial, kemudian dilakukan perancangan kisi-kisi dan dan instrumen validasi modul untuk mengukur kelayakan modul oleh pakar serta soal tes untuk menguji efektifitas penggunaan modul. Adapun kisi-kisi lembar kelayakan modul sosiologi yang telah dikembangkan memuat beberapa aspek yaitu aspek isi, keterbatasan bahasa, kejelasan bahasa, penyajian materi, gambar, dan kemudahan pengguna. Jumlah pernyataan yang dapat mengukur kelayakan modul terdiri dari 18 butir, dengan rincian masing-masing aspek dapat dilihat pada tabel 3 berikut ini:

Tabel 3. Kisi-kisi Lembar Kelayakan Modul

\begin{tabular}{clc} 
No. & \multicolumn{1}{c}{ Aspek } & No Butir \\
\hline 1. & Isi & $(1-7)$ \\
\hline 2. & Keterbatasan bahasa & $(1-3)$ \\
\hline 3. & Kejelasan bahasa & $(1-2)$ \\
\hline 4. & Penyajian materi & $(1-2)$ \\
\hline 5. & Gambar & $(1-2)$ \\
\hline 6. & Kemudahan pengguna & $(1-2)$
\end{tabular}

Sumber: Hasil Penelitian (2021).

Tahap Develop (Pengembangan)

Tahap pengembangan atau develop yaitu tahap yang menghasilkan produk sumber belajar sebagai modul yang telah mendapatkan kelayakan dan saran perbaikan dari validator dan praktisi. Proses kelayakan produk ini menggunakan instrumen kelayakan yang telah dikembangkan. Aspek

Jurnal Sikola: Jurnal Kajian Pendidikan dan Pembelajaran Vol. 3, No. 2, Th. 2021 
yang dinilai pada kelayakan modul yaitu aspek isi, aspek bahasa, aspek penyajian materi, aspek kegrafisan, dan aspek kemudahan pengguna. Hasil kelayakan modul didapat oleh 3 orang ahli yang telah memberikan kelayakan yakni 2 orang dosen jurusan sosiologi Fakultas Ilmu Sosial di Universitas Negeri Padang dan 1 orang guru sosiologi di SMA Adabiah Padang.

Tabel 4. Hasil Analisis Skor Kelayakan Modul

\begin{tabular}{|c|c|c|c|}
\hline No. & Indikator Komponen & $\begin{array}{c}\text { Skor } \\
\text { Kelayakan }\end{array}$ & Keterangan \\
\hline 1. & Kesesuaian materi dengan kurikulum 2013 & 0,83 & Sangat Kuat \\
\hline 2. & Materi yang disajikan sesuai dengan KI & 0,83 & Sangat Kuat \\
\hline 3. & Materi yang disajikan sesuai dengan KD & 0,89 & Sangat Kuat \\
\hline 4. & $\begin{array}{l}\text { Tidak terjadi kesalahan konsep pada materi } \\
\text { yang disajikan }\end{array}$ & 0,83 & Sangat Kuat \\
\hline 5. & Modul dilengkapi dengan peta konsep & 0,89 & Sangat Kuat \\
\hline 6. & Modul dilengkapi dengan soal & 0,83 & Sangat Kuat \\
\hline 7. & $\begin{array}{l}\text { Soal yang disajikan dalam modul dikaitkan } \\
\text { dengan kehidupan sehari-hari }\end{array}$ & 0,83 & Sangat Kuat \\
\hline 8. & $\begin{array}{l}\text { Bahasa yang disajikan menggunakan cita } \\
\text { rasa modul dengan memperhatikan ejaan } \\
\text { yang baik dan benar }\end{array}$ & 0,99 & Sangat Kuat \\
\hline 9. & Menggunakan kata atau istilah dengan tepat & 0,89 & Sangat Kuat \\
\hline 10. & $\begin{array}{l}\text { Menggunakan kalimat dengan baik dan } \\
\text { benar }\end{array}$ & 0,89 & Sangat Kuat \\
\hline XI. & $\begin{array}{l}\text { Bahasa yang digunakan sederhana, dan } \\
\text { mudah dipahami }\end{array}$ & 0,89 & Sangat Kuat \\
\hline 12. & $\begin{array}{l}\text { Bahasa sesuai dengan tingkat pertumbuhan } \\
\text { peserta didik }\end{array}$ & 0,89 & Sangat Kuat \\
\hline 13. & $\begin{array}{l}\text { Materi yang disajikan mengaitkan suatu } \\
\text { konsep dengan konsep yang lainnya dalam } \\
\text { menjelaskan suatu fenomena }\end{array}$ & 0,89 & Sangat Kuat \\
\hline 14. & $\begin{array}{l}\text { Materi yang disajikan mengaitkan suatu } \\
\text { konsep dengan kehidupan nyata }\end{array}$ & 0,83 & Sangat Kuat \\
\hline 15. & Kualitas gambar baik dan tidak pecah & 0,89 & Sangat Kuat \\
\hline 16. & $\begin{array}{l}\text { Gambar pada halaman judul sesuai dengan } \\
\text { isi materi }\end{array}$ & 0,83 & Sangat Kuat \\
\hline 17. & $\begin{array}{l}\text { Penyajian materi memuat gambar-gambar } \\
\text { penunjang materi }\end{array}$ & 0,89 & Sangat Kuat \\
\hline 18. & Penyajian gambar sesuai dengan kehidupan & 0,89 & Sangat Kuat \\
\hline
\end{tabular}

\section{Tahap Disseminate (Penyebaran)}

Tahap penyebaran atau disseminate adalah tahap terakhir dalam penelitian pengembangan modul sosiologi sesuai dengan model pengembangan $4 \mathrm{D}$. Penyebaran atau disseminate adalah tahap setelah modul yang dikembangkan dinyatakan layak oleh para validator. Tahap disseminate dilakukan dengan cara mengujicobakan modul pada proses pembelajaran dan menguji efektifitas modul sosiologi materi integrasi sosial. Dalam penelitian ini tahap penyebaran dilakukan pada satu kelas XI IPS 1 SMA Adabiah Padang. 


\section{Efektivitas Modul}

\section{Soal Pretest-Posttest}

Untuk mengetahui efektifitas penerapan modul ini dalam pembelajaran sosiologi maka peneliti terlebih dahulu memberikan soal pretest kepada peserta didik, kemudian selanjutnya diberi posttest diakhir pembelajaran pada materi integrasi sosial. Selanjutnya hasil pretest dan posttest ini dibandingkan dan dianalisis menggunakan rumus uji t-test. Berikut adalah hasil perbandingan yang memperlihatkan efektivitas penggunaan modul sosiologi materi integrasi sosial yang telah dikembangkan dan dianalisis dengan program SPSS versi 22 Analyze Paired-Sample T-Test. Secara ringkas untuk melihat hasil dapat dicermati dalam tabel dibawah ini:

Tabel 5. Analisis Deskriptif Skor Pre Test dan Post Test

\begin{tabular}{cccccc}
\hline \multicolumn{5}{c}{ Paired Samples Statistics } \\
\hline & Mean & N & Std. Deviation & $\begin{array}{c}\text { Std. Error } \\
\text { Mean }\end{array}$ \\
\hline \multirow{2}{*}{ Pair 1} & Pre test & 64.58 & 24 & 8.198 & 1.673 \\
\cline { 2 - 6 } & Post test & 86.46 & 24 & 4.773 & 0.974 \\
\hline & & Sumber: Hasil Penelitian (2021).
\end{tabular}

Pada tabel paired samples statistic diperlihatkan hasil analisis statistik deskriptif diperoleh dari skor pretest-posttest. Untuk skor pretest mendapatkan rata-rata 64.58 , sedangkan pada skor posttest mendapatkan rata-rata sebesar 86.46. Banyaknya peserta didik yang digunakan sebagai sampel penelitian berjumlah 24 peserta didik. Skor standar deviasi pretest sebesar 8.198 dan posttest sebesar 4.773. Terakhir yaitu skor Std. Error Mean pada pretest rata-rata 1.673 dan posttest rata-rata 974. Karena hasil belajar mendapatkan skor rata-rata pretest $64.58<$ posttest 86.46 maka diartikan secara deskriptif ada perbandingan rata-rata hasil belajar antara pretest dengan posttest.

Tabel 6. Hasil Efektivitas Modul Sosiologi Materi Integrasi Sosial

\begin{tabular}{|c|c|c|c|c|c|c|c|c|c|}
\hline \multicolumn{10}{|c|}{ Paired Samples Test } \\
\hline & & \multicolumn{5}{|c|}{ Paired Differences } & \multirow{3}{*}{$\mathrm{t}$} & \multirow{3}{*}{ df } & \multirow{3}{*}{$\begin{array}{l}\text { Sig. (2- } \\
\text { tailed) }\end{array}$} \\
\hline & & \multirow[t]{2}{*}{ Mean } & \multirow[t]{2}{*}{$\begin{array}{c}\text { Std. } \\
\text { Deviation }\end{array}$} & \multirow{2}{*}{$\begin{array}{l}\text { Std. } \\
\text { Error } \\
\text { Mean }\end{array}$} & \multicolumn{2}{|c|}{$\begin{array}{l}95 \% \text { Confidence } \\
\text { Interval of the } \\
\text { Difference }\end{array}$} & & & \\
\hline & & & & & Lower & Upper & & & \\
\hline Pair 1 & Pre test \& Post test & -21.875 & 8.699 & 1.776 & -25.548 & -18.202 & -12.319 & 23 & 0.000 \\
\hline
\end{tabular}

Sumber: Hasil Penelitian (2021).

Berdasarkan pada tabel paired sample test diketahui nilai Sig. (2-tailed) yaitu sebesar $0.000<$ 0,05 . Selanjutnya dapat dilihat t hitung yaitu 12.319. Menurut Singgih Santoso aturan dinamis dalam contoh uji paired sample t-test berdasarkan pada makna signifikan hasil dari SPSS adalah sebagai berikut : (1) Jika nilai Sig. (2-tailed) < 0,05, maka H0 ditolak dan H1 diakui; (2) Sebaliknya jika nilai Sig. (2-tailed) > 0,05 maka H0 diakui dan H1 ditolak (Singgih, 2014), artinya dalam penelitian ini dapat disimpulkan terdapat pengaruh dalam penggunaan modul yang telah dikembangkan.

\section{Pembahasan}

Tujuan penelitian ini adalah menghasilkan produk pengembangan berupa modul sosiologi pada materi integrasi sosial yang layak digunakan pada pembelajaran sosiologi untuk meningkatkan kompetensi peserta didik khususnya kognitif. Dalam menghasilkan produk ini 
peneliti melalui proses uji kelayakan, ujicoba dan mengetahui efektivitas modul yang telah dihasilkan.

\section{Kelayakan Produk Modul Sosiologi}

Kelayakan produk modul sosiologi yang dihasilkan diperoleh dari hasil penilaian ahli melalui instrumen validitas. Validitas merupakan syarat terpenting dalam suatu alat evaluasi (Yusuf, 2016). Sebelum guru menggunakan suatu modul ini, maka pengembang produk pembelajaran hendaknya mengukur terlebih dahulu derajat validitasnya berdasarkan kriteria tertentu. Dengan kata lain, untuk melihat apakah modul tersebut valid (sahih). Adapun jenis-jenis validitas yaitu validitas permukaan (face validity), validitas isi (content validity), validitas empiris, dan validitas konstruk (construct validity). (Arifin, 2009). Dalam penelitian ini validitas yang dinilai oleh ahli melalui instrumen validasi modul adalah validitas isi dan validitas permukaan, dengan indikator yang dinilai yaitu isi modul, keterbatasan bahasa, kejelasan bahasa, penyajian materi, gambar, dan kemudahan penggunaan.

\section{Efektivitas}

Sumarina dalam Husni Wakhyudin dan Ika Diah Kurniawati (Husni Wakhyudin, 2014), menjelaskan bahwa "efektivitas adalah suatu ukuran yang menyatakan seberapa jauh target (kuantitas, kualitas dan waktu) telah tercapai". Efektivitas menunjukkan seberapa jauh tercapainya suatu tujuan yang telah ditentukan. Suatu produk (modul) dikatakan efektif apabila adanya pengaruh kepada penggunanya, bisa diartikan sebagai kegiatan yang bisa memberikan hasil belajar yang memuaskan setelah menggunakan modul. Untuk menentukan efektivitas atau tidak efektivitasnya modul Sosiologi materi Integrasi Sosial yang digunakan dalam pembelajaran Sosiologi SMA kelas XI pada penelitian ini, cara yang dilakukan yaitu menghitung skor tes hasil belajar peserta didik yang diperoleh sebelum dan sesudah penggunaan. Apabila skor tes hasil belajar peserta didik memenuhi ketuntasan klasikal, yaitu jika jumlah peserta didik yang tuntas belajarnya $\geq 85 \%$ dari seluruh peserta didik mendapatkan skor lebih besar atau sama dengan Kriteria Ketuntasan Minimum (KKM).

Berdasarkan hasil analisis tes pembelajaran menggunakan modul modul Sosiologi materi Integrasi Sosial, diperoleh bahwa pembelajaran menggunakan modul ini merupakan hal yang baru bagi peserta didik baik terhadap materi dan modul, karena peserta didik dalam proses pembelajaran baru kali ini menggunakan modul integratif dalam pembelajarannya yang mencakup peta konsep, pengalaman belajar yang sesuai dengan model yang diterapkan oleh guru dan rangkuman serta evaluasi, juga suasana belajar dan cara guru mengajar saat proses pembelajaran Sosiologi baru karena dalam belajar diimplikasikan dengan model pembelajaran Discovery Learning khususnya materi Integrasi Sosial. Peserta didik senang terhadap materi, modul, suasana belajar, dan cara guru mengajar saat proses pembelajaran Sosiologi karena guru mengajar dengan cara baru di dalam kelas, pembelajaran tidak terfokus pada guru saja. Peserta didik berminat dan tertarik mengikuti pembelajaran karena materi yang dipaparkan di dalam modul mudah dipahami oleh peserta didik, karena di dalam modul disertai dengan contoh konsep, soal dan pembahasan yang diberikan sehingga peserta didik mudah memahami latihan-latihan selanjutnya yang diberikan. Teori yang disampaikan oleh para ahli sesuai dengan efektivitas modul Sosiologi materi Integrasi Sosial ini dimana peserta didik memberikan respon yang sangat positif, bahwa diperoleh respon peserta 24 peserta didik untuk setiap indikator rata-rata di atas $70 \%$ dimana rata-rata hasil belajar keseluruhan indikator diperoleh 86,46.

Hasil belajar merupakan hal yang dapat dipandang dari dua sisi yaitu sisi siswa dan sisi guru. Dari sisi siswa, hasil belajar merupakan tingkat perkembangan mental yang lebih baik bila dibandingkan pada saat sebelum belajar. Tingkat perkembangan mental tersebut terwujud pada jenis-jenis ranah kognitif, afektif, dan psikomotor. Sedangkan dari sisi guru, hasil belajar merupakan saat terselesaikannya bahan pelajaran. Hasil belajar ditentukan dengan evaluasi. Evaluasi hasil belajar merupakan proses untuk menentukan nilai belajar siswa melalui kegiatan

Jurnal Sikola: Jurnal Kajian Pendidikan dan Pembelajaran Vol. 3, No. 2, Th. 2021 
penilaian dan pengukuran yang dicapai siswa setelah mengikuti suatu kegiatan pembelajaran. Tingkat keberhasilan dapat dinyatakan dalam huruf, kata atau simbol. Untuk mengetahui tingkat keberhasilan siswa dalam mencapai tujuan, maka evaluasi hasil belajar memiliki sasaran berupa ranah-ranah yang terkandung dalam tujuan. Hasil belajar selalu berhubungan satu sama lain. Dalam proses belajar mengajar di sekolah saat ini tipe hasil belajar kognitif lebih dominan daripada afektif dan psikomotorik.

Sebelum proses pembelajaran banyak faktor yang terlibat dan saling mempengaruhi dan tentu saja menentukan berhasil tidaknya suatu proses pembelajaran. Menurut Oemar Hamalik (Malik, 2003) terdapat tujuh komponen yang mempengaruhi proses belajar mengajar yakni: (1) tujuan mengajar; (2) siswa yang belajar; (3) guru yang mengajar; (4) metode mengajar; (5) alat bantu mengajar; (6) penilaian evaluasi; dan (7) situasi pengajaran. Pada bagian lain Ngalim Purwanto (Purwanto, 2002) mengemukakan ciri-ciri dan prinsip-prinsip balajar. Ciri-ciri belajar tersebut meliputi empat hal yang hampir sama dengan pendapat ahli sebelumnya yaitu: 1) belajar merupakan perubahan tingkah laku; 2) belajar merupakan perubahan melalui latihan. 3) untuk disebut belajar maka perbuatan itu harus relatif menetap. 4) tingkah laku yang mengalami perubahan oleh karena belajar menyangkut berbagai aspek kepribadian baik fisik maupun psikis.

Uraian-uraian menegaskan pentingnya guru menyusun sendiri prinsip belajar yang dapat dilaksanakan dalam situasi dan kondisi yang berbeda dan setiap siswa secara individual. Adapun prinsip-prinsip belajar itu adalah sebagai berikut: a) dalam belajar setiap siswa harus diusahakan partisipasi aktif, meningkatkan minat dan membimbing untuk mencapai tujuan intruksional; $b$ ) belajar bersifat keseluruhan dan materi itu harus memiliki struktur, penyajian yang sederhana, sehingga siswa mudah menangkap pengertiannya; c) belajar harus dapat menimbulkan motivasi yang kuat pada siswa untuk mencapai tujuan intruksional; d) belajar itu proses kontinyu, maka harus tahap demi tahap menurut perkembangannya; e) belajar memerlukan sarana cukup, sehingga anak dapat belajar dengan tenang; f) belajar perlu ada interaksi anak dengan lingkungannya. Dari beberapa pendapat di atas maka dapat disimpulkan bahwa belajar merupakan proses atau serangkaian kegiatan yang menghasilkan perubahan pada diri seseorang yang terjadi melalui latihan dan pengalaman sebagai hasil interaksi tersebut ditunjukkan dalam berbagai bentuk seperti perubahan pengetahuan, sikap, tingkah laku, keterampilan serta kebiasaan. Belajar sebagai kegiatan individu sebenarnya merupakan rangsangan-rangsangan individu yang dikirim kepadanya oleh lingkungan. Dengan demikian terjadinya kegiatan belajar yang dilakukan oleh seorang individu dapat berjalan dengan baik jika terjadi interaksi antara individu dengan lingkungannya yang dipandu melalui sebuah modul yang dirancang oleh guru agar peserta didik mampu mengkonstruksi fenomena yang ditemuinya di lingkungan sekitarnya dan konsep yang harus dikuasainya.

Menurut Nana Sudjana (Sudjana, 1995) hasil belajar yang dicapai dipengaruhi dua faktor utama, yakni: faktor dalam diri sendiri dan faktor yang datang dari luar diri atau faktor lingkungan. Faktor yang datang dari dalam diri terutama kemampuan yang dimiliki. Faktor kemampuan besar sekali pengaruhnya terhadap keberhasilan belajar yang dicapai. Hasil belajar di sekolah $70 \%$ dipengaruhi oleh kemampuan yang dimiliki dan 30\% dipengaruhi oleh faktor dari luar yaitu faktor lingkungan. Selain faktor di atas ada faktor-faktor lain yang mempengaruhi hasil belajar atau prestasi belajar. Faktor-faktor yang mempengaruhi prestasi belajar menurut Slameto (Slameto, 2010) dapat dirinci sebagai berikut: Pertama, faktor internal, meliputi: (a) faktor jasmaniah: terdiri dari faktor kesehatan dan cacat tubuh; (b) faktor fisiologis: terdiri dari intelegensi, perhatian, minat, bakat, motif, kematangan, dan kedisiplinan; (c) faktor kelelahan: terdiri dari kelelahan jasmani dan rohani. Kedua, faktor eksternal, meliputi: (a) faktor keluarga: terdiri dari cara orang tua mendidik, relasi antar anggota keluarga, suasana rumah, keadaan ekonomi keluarga, pengertian orang tua, dan talar belakang kebudayaannya; (b) faktor sekolah: terdiri dari metode mengajar, kurikulum, relasi guru dengan siswa, disiplin siswa, keadaan gedung dan tugas rumah; (c) faktor kegiatan masyarakat: terdiri dari kegiatan siswa dalam masyarakat, mass media, teman bergaul, dan bentuk kehidupan masyarakat. Sedangkan menurut 
Muhibbinsyah (2002: 139) selain faktor internal dan eksternal, juga terdapat faktor pendekatan belajar, yaitu "pendekatan belajar dapat dipahami sebagai segala cara strategi yang digunakan siswa dalam menunjang efektivitas dan efisiensi proses pembelajaran materi tertentu. Penjelasan ini menegaskan bahwa penting guru merancang pembelajaran yang sesuai dengan keadaan karakteristik peserta didik dan materi yang akan dikuasai sehingga hasil belajar yang dicapai dapat sesuai dengan tujuan pembelajaran dan meningkatkan kompetensi peserta didik, sehingga hasil penelitian ini memperlihatkan setelah digunakannya modul pada proses pembelajaran sosiologi materi integrasi sosial di kelas XI IPS 1 SMA Adabiah Padang kemampuan peserta didik mencapai kategori baik atau meningkat. Dengan dikembangkannya modul sosiologi pada materi integrasi sosial peserta didik yang sebelumnya tidak pernah menggunakan modul dalam proses pembelajaran menjadi tertarik dengan proses pembelajaran menggunakan modul serta peserta didik juga menyukai tampilan modul yang praktis.

\section{Kesimpulan}

Pada penelitian ini telah dikembangkan produk berupa modul sosiologi pada materi integrasi sosial dan dinyatakan layak untuk digunakan dalam pembelajaran sosiologi. Hasil penelitian menunjukkan bahwa pengembangan modul dinyatakan layak untuk digunakan dalam pembelajaran sosiologi yang sudah melewatkan tahap pengembangan yang sesuai dengan prosedur dan diberi kelayakan oleh ahli materi dengan hasil 0,87 dengan kategori sangat layak. Nilai pretest diperoleh hasil rata-rata 64,58 sedangkan hasil rata-rata posttest sebesar 86.46. Maka berdasarkan hasil penelitian tersebut, terdapat peningkatan hasil belajar peserta didik.

\section{Daftar Pustaka}

Ahmad, A. R. H. dan A. (1995). Pengelolaan Pengajaran. Jakarta: Rineka Cipta.

Arifin, Z. (2009). Evaluasi Pembelajaran. Bandung: PT. Remaja Rosdakarya.

Direktorat Tenaga Kependidikan. (2008). Penulisan Modul. Jakarta: Kemendikbud.

Gintings, A. (2008). Esensi Praktis Belajar dan Pembelajaran. Bandung: Humaniora.

Husni Wakhyudin, I. D. K. (2014). Efektivitas Model Think Pair Share dalam Pembelajaran Tematik Integratif terhadap Kemampuan Pemecahan Masalah. MALIH PEDDAS (Majalah Ilmiah Pendidikan Dasar), 4(1), 57-66.

Majid, A. (2008). Perencanaan Pembelajaran, Mengembangkan Standar Kompetensi Guru. Bandung: Remaja Rosdakarya.

Malik, O. (2003). Media Pendidikan. Bandung: Alumni.

Mulyasa, E. (2010). Menjadi Guru Profesional (Menciptakan Pembelajaran Kreatif dan Menyenangkan) (IX). Bandung: Remaja Rosdakarya.

Purwanto, N. (2002). Psikologi Pendidikan. Bandung: Remaja Rosdakarya.

Santika, A., \& Sylvia, I. (2021). Efektivitas E-Modul Berbasis Anyflip untuk Meningkatkan Kemampuan Penguasaan Materi Peserta Didik pada Materi Nilai dan Norma Sosial Kelas X di SMA N 3 Payakumbuh. Jurnal Sikola: Jurnal Kajian Pendidikan Dan Pembelajaran, 2(4), 285-296. https://doi.org/10.24036/sikola.v2i4.128

Singgih, S. (2014). SPSS 22 from Essential to Expert Skills. Jakarta: Gramedia.

Slameto, S. (2010). Belajar Dan Faktor-Faktor Yang Mempengaruhi. Jakarta: Rineka Cipta.

Sudjana, N. (1995). Penilaian Hasil Proses Belajar Mengajar. Bandung: Remaja Rosdakarya.

Sudjana, N., \& Rivai, A. (2007). Teknologi Pengajaran. Jakarta: Kencana.

Sugiyono, S. (2017). Metode Penelitian Kuantitatif, Kualitatif, dan R\&D. Bandung: Alfabeta.

Suntari, B., \& Widyarso, W. (2015). Modul Pengembangan Keprofesian Berkelanjutan Mata Pelajaran Sosiologi SMA Kelompok Kompetensi 9. Jakarta: Direktorat Jenderal Guru dan Tenaga Kependidikan Kementrian Pendidikan dan Kebudayaan. 
Suparman, S. (2014). Peningkatan Kemandirian Belajar dan Minat Belajar Mahasiswa Mata Kuliah Elektronika Analog dengan Pembelajaran PBL. Jurnal Pendidikan Teknologi Dan Kejuruan, 22(1), 83-88. https://doi.org/10.21831/jptk.v22i1.8840

Thiagarajan, S. (1974). Instructional Development for Training Teachers of Exceptional Children. Washington, DC: National Center for Improvement Educational System.

Yusuf, A. M. (2016). Metode Penelitian Kuantitatif, Kualitatif \& Penelitian Gabungan. Jakarta: Prenada Media. 